\title{
In-vivo antioxidant activity of different fractions of INDIGOFERA BARBERI against paracetamol induced toxicity in rats
}

\author{
Shaik Aminabee ${ }^{1}$, Atmakuri Lakshmana Rao ${ }^{1 *}$, MaramChinna Eswaraiah $^{2}$ \\ ${ }^{1}$ Department of Pharmacology, V. V. Institute of Pharmaceutical Sciences, Gudlavalleru, A.P., \\ India \\ ${ }^{2}$ Department of Pharmacognosy, Anurag College of Pharmacy, Kodad, T.S., India
}

\section{*Correspondence:}

Dr. Shaik Aminabee

Associate Professor

Department of Pharmacology

V. V. Institute of Pharmaceutical Sciences

Gudlavalleru, A.P., India,

E-mail: aminaammi786@gmail.com

\section{ABSTRACT}

Aim: To evaluate the in-vivo antioxidant activity of chloroform extract fractions of Indigofera barberi (whole plant) against paracetamol induced toxicity in rats.

Methods: For 7 days, animais were treated with chloroform extract fractions and the toxicity was induced with a single dose of paracetamol intra peritoneal injection. Group of animals pretreated with $100 \mathrm{mg} / \mathrm{kg}$ p.o of fraction D of Indigofera barberi improved the SOD, catalase, peroxidase and glutathione levels significantly as compared to control group.

Results: The results showed that the activities of SOD, catalase, peroxidase and glutathione in group treated with paracetamol are $33.6 \pm 0.09,5.5 \pm 0.23,0.131 \pm 0.15 \& 46.1 \pm 5.81$ and SOD, catalase, peroxidase $\&$ glutathione in fraction D treated group are $61.8 \pm 0.07,10.6 \pm 0.16,0.913$ $\pm 0.23 \& 87.6 \pm 1.4$ respectively. So, the present study revealed that fraction D of Indigofera barberi has significant in-vivo antioxidant activity and can be used to protect tissue from oxidative stress.

Conclusion: From the results, fraction D of Indigofera barberi in the dose of $100 \mathrm{mg} / \mathrm{kg}$, p.o. has improved the SOD, catalase, peroxidase and glutathione levels significantly. Based on this 
study we conclude that fraction D of Indigofera barberi possesses in-vivo antioxidant activity and can be employed in protecting tissue from oxidative stress.

Key words: Indigofera barberi, Paracetamol, Sylimarin, Radical scavenging.

\section{INTRODUCTION}

Today $80 \%$ (approximately) of the total world population rely purely on plants for their fitness and ease. Not long ago, there has an augment of intrigue in the therapeutic prospective of curative plants as antioxidants in minimizing free radical instigated tissue damage. In reaction to this, increased acceptance and significant demand for curative and herbal plants, a ordinal number of supervising organizations and groups are mentioning that indigenous curative plants have been brought into agriculture ${ }^{1}$. Many plants generate various bioactive molecules and make them a principle and plentiful source of distinct novel kinds of medicines. A huge heritage of scrutiny and knowledge to prophylactic and remedial medicines was accessible in ancient scholastic efforts included in the Charaka, Atharva veda and Sushruta etc $^{2}$. Above $50 \%$ of all current clinical medicines are of natural product source ${ }^{3}$ and many natural products do a vital part in medicine evolution process in the pharmaceutical production ${ }^{4}$. Herbal medicines and products have acquired significance in modern years because of their capability and price value. Therefore, there was an increasing fascination in the quantification and utilization of plant antioxidant for systematic investigation as well as commercial (cosmetic, pharmaceutical and dietary) purposes. The different antioxidant responses include many steps involving the initiation, propagation, dividing, hindrance and cessation of free radicals. Oxidative free radicals are originated when cells utilizes oxygen for different physiological procedures. Generally byproducts are ROS (Reactive Oxygen Species) like hypochlorous acid (HClO), super oxide anion $\left(\mathrm{O}_{2}{ }^{-}\right)$, hydrogen peroxide $\left(\mathrm{H}_{2} \mathrm{O}_{2}\right)$ and hydroxyl radical $(\mathrm{OH})$ that evolve by the cellular redox action. At modest concentrations but at high levels, ROS apply favorable results on cellular operations and immune reactions and are pivotal for life; ROS produces oxidative stress that causes cell structures and functions impairment, involving DNA, lipids, sugars and proteins 5 . Oxidative pressure plays a crucial segment in the evolution of degenerative and chronic ailments like skin diseases, cancer, autoimmune disorders, altitude sickness, cataract, rheumatoid arthritis, osteoarthritis, coronary heart disease, aging and various neurodegenerative diseases ${ }^{6}$. Antioxidants, either in-situ (naturally produced) or outmost supplied via diet hinder oxidative 
pressure in human body. These antioxidants efficient of scavenging the free radicals react by prohibiting injury caused by ROS, and thereafter enhance the cellular response, immune defense, other degenerative diseases and lower the risk of cancer $^{5}$.

Recently, many herbal medicines have been gaining much surveillance as alternative drugs ${ }^{7}$ applicable for prophylactics for life style associated disorders and comparatively very minimal knowledge is accessible regarding their mechanism of action. There was an extended interest in the investigation of plant outcomes which has prompted enormous research on their possible fitness benefits. Traditional usages (Ayurveda), of plants are most familiar in aqueous extracts form. Closely, some of the papers explored focus for examining these plants in aqueous or ethanolic extracts and some have been described activity in petroleum ether, chloroform and benzene extracts ${ }^{8-10}$.

Indigofera barberi (Fabaceae) of Tirumala Hills is peak assessed endemic herb. Vernacularly it is known as Adavineelimanadu mokka. It grows up to $1 \mathrm{~m}$ tall (under shrub). Branchlets are faintly angled. Leaves are 3 and they are foliolate. Leafiets are pubescent, ovate-oblong, mucronate, obtuse. Flowers (pink) are organized in axillary congested racemes. Pods are appressed, deflexed, sub-terete, sharply pointed, white-tomentose. Seeds are 2 to 4 in number. September to December is the flowering and fruiting season ${ }^{11}$.

Orally, leaf powder $(5 \mathrm{~g})$ is administered through butter milk for controlling diabetes. Leaves (50 $\mathrm{g})$, pepper $(1 \mathrm{~g})$, and garlic $(1 \mathrm{~g})$ are made into paste and formulated to pills of peanut size, for 5 days 5 pills are administered once a day to cure jaundice as authorized by Nakkala and many tribal physicians. Whole plant powder $(5 \mathrm{~g})$ is administered through rice washed water once a day for 10-15 days to remove intestinal worms and as a remedy for various types of peptic ulcers and skin diseases ${ }^{12}$. Used as a coloring agent and dye. Leaf juice was utilized as an antiseptic to burns, cuts, cure wounds and boils. Keeping these considerations in mind, the current study was accepted to fabricate a scientific base for the use of the fractions of chloroform extract of Indigofera barberi as an antioxidant agent.

\section{MATERIALS AND METHODS}

\section{Collection of materials}

The Indigofera barberi (whole plant, Herbarium number: VVIPS/PCL/011) was accumulated from the evergreen forest of Tirumala Hills in Andhra Pradesh (AP) State, India. Samples were authenticated and certified by Dr. K. Madhava Chetty, Plant Taxonomist, Department of Botany, 
Sri Venkateswara University (SVU), Tirupati, India. For one week, the Indigofera barberi (whole plant) were sorted, ranked, cleaned and air-dried at room temperature. By utilizing the laboratory hammer mill plant was finely grounded into powder. Finely powdered samples were gathered and tightly stored in water and air proof containers shielded from heat and direct sunlight until needed for extraction.

\section{Preparation of extracts}

After completely grounding the Indigofera barberi (whole plant) into fine powder, it was successively extracted for 18 hours with various solvents of increasing polarity i.e., ywith petroleum ether, ethyl acetate, chloroform, ethanol and distilled water in soxhlet apparatus. The obtained extracts were concentrated to dryness in rota evaporator till free from the solvents.

\section{Isolation of fractions}

Thin-layer chromatography method was carried out using silica gel aluminum plate 60F-254, 0.5 mm (TLC plates, Merck). The obtained spots were visualized in UV light and $10 \% \mathrm{of}_{2} \mathrm{SO}_{4}$ in methanol. More number of spots was seen with chloroform extract. So for further purification, the chloroform extract was subjected to column chromatography using silica gel of pore size 60-100. The silica gel column was equilibrated and counter balanced for 1 hour with petroleum ether at flow rate $5 \mathrm{ml} / \mathrm{min}$. The chloroform extract ( $1 \mathrm{~g}$ dissolved in methanol) was loaded on to the column and 11 fractions were collected using different solvents of varying concentrations like petroleum ether $(100 \%)$, petroleum ether:ethyl acetate $(4: 1)$, petroleum ether:ethyl acetate (2:3), petroleum ether:ethyl acetate (3:2), ethyl acetate (100\%), chloroform:methanol $(2: 3)$, chloroform:methanol (3:2).

Phytochemical analysis

After isolation of fractions from chloroform extract, phytochemical analysis ${ }^{13}$ of fractions was carried out for the presence of alkaloids, tannins, saponins, glycosides, terpenoids, carbohydrates, flavonoids, proteins, amino acids, fixed oils, steroids \& sterols by different methods

Animals

Albino wistar rats of both the sex weighing 180-200 g were procured from National Institute of Nutrition, Hyderabad, Telangana, India. The animals are kept stayed in polypropylene cages (5 in each cage) at a relative humidity of $55-65 \%$ and medium temperature of $25 \pm 2^{\circ} \mathrm{C}$. A 12 hour light and dark cycle was retained in the air conditioned animal house. After arrival, all the rats 
are nourished with common diet and distilled water for atleast 1 week and thenthey are equally divided into categories with free access to food and distilled water.

Acute toxicity studies

According to Organization for Economic Co-Operation and Development (OECD) guidelines ${ }^{14}$ 143, acute toxicity studies were performed. Animals were divided in groups and each group contains 5 animals. These grouped animals are fasted for 4 hours with free access to distilled water only. The fractions are administered orally in doses of $100,300,1500,3000 \mathrm{mg} / \mathrm{kg}$ to different groups of rats and observed over 14 days for mortality and physical/behavioral changes.

\section{Experimental}

Group-I animals served as normal control, they receive only vehicle (guim acacia 3\% solution)

Group-II animals served as toxic control, treated with paracetamol in a single dose of $2 \mathrm{~g} / \mathrm{kg}$, orally to produce acute toxicity

Group-III served as standard group and was treated with sylimarin $(100 \mathrm{mg} / \mathrm{kg})$

Group-IV was treated with fraction A $50 \mathrm{mg} / \mathrm{kg}$

Group-V was treated with fraction A $100 \mathrm{mg} / \mathrm{kg}$

Group-VI was treated with fraction B $50 \mathrm{mg} / \mathrm{kg}$

Group-VII was treated with fraction B $100 \mathrm{mg} / \mathrm{kg}$

Group-VIII was treated with fraction C $50 \mathrm{mg} / \mathrm{kg}$

Group-IX was treated with fraction C $100 \mathrm{mg} / \mathrm{kg}$

Group-X was treated with fraction D $50 \mathrm{mg} / \mathrm{kg}$

Group-XI was treated with fraction D $100 \mathrm{mg} / \mathrm{kg}$

The animals of groups III to XI were treated with single dose of paracetamol $2 \mathrm{~g} / \mathrm{kg}$, orally, 6 hours after the last treatment. On $8^{\text {th }}$ day the rats are sacrificed by carotid bleeding and liver were rapidly excised, rinsed in ice-cold saline, and a $10 \% \mathrm{w} / \mathrm{v}$ homogenate was prepared using $0.15 \mathrm{M}$ $\mathrm{KCI}$, centrifuged at $800 \mathrm{rpm}$ for $10 \mathrm{~min}$ at $4^{\circ} \mathrm{C}$. The supernatant obtained was used for the estimation of catalase and peroxidase and other enzymes. Further, the homogenate was centrifuged at $1000 \mathrm{rpm}$ for $20 \mathrm{~min}$ at $4^{\circ} \mathrm{C}$ and the supernatant was used for biochemical estimation.

\section{BIOCHEMICAL ESTIMATION}

Estimation of SOD 
The assay of superoxide dismutase (SOD) was based on the reduction of nitro blue tetrazolium (NBT) to water insoluble blue formazan, per the method of Beauchamp and Fridovich ${ }^{15}$. Liver homogenate $(0.5 \mathrm{ml})$ was taken and $1 \mathrm{ml}$ of $50 \mathrm{mM}$ sodium carbonate, $0.4 \mathrm{ml}$ of $24 \mathrm{mM}$ NBT and $0.2 \mathrm{ml}$ of $0.1 \mathrm{mM}$ EDTA were added. The reaction was initiated by adding $0.4 \mathrm{ml}$ of $1 \mathrm{mM}$ hydroxylamine hydrochloride. Zero time absorbance was taken at $560 \mathrm{~nm}$ followed by recording the absorbance after $5 \mathrm{~min}$ at $25^{\circ} \mathrm{C}$. The control was simultaneously run without liver homogenate. Units of SOD activity were expressed as the amount of enzyme required to inhibit the reduction of NBT by 50\%. The specific activity was expressed in terms of units per milligram of proteins.

\section{Estimation of catalase}

Catalase activity was measured by the method of Aebi ${ }^{16}$. Supernatant liquid $(0.1 \mathrm{ml})$ was added to cuvette containing $1.9 \mathrm{ml}$ of $50 \mathrm{mM}$ phosphate buffer $(\mathrm{pH} 7.0)$. Reaction was started by the addition of $1.0 \mathrm{ml}$ of freshly prepared $30 \mathrm{mM} \mathrm{H} \mathrm{H}_{2}$. The rate of decomposition of $\mathrm{H}_{2} \mathrm{O}_{2}$ was measured spectrophotometrically from changes in absorbance at $240 \mathrm{~nm}$. Activity of catalase was expressed as units/mg protein.

\section{Estimation of peroxidase}

The peroxidase assay was carried out per the method of Nicholos ${ }^{17}$. Liver homogenate $(0.5 \mathrm{ml})$ was taken, and to this were added $1 \mathrm{ml}$ of $10 \mathrm{mM} \mathrm{KI}$ solution and $1 \mathrm{ml}$ of $40 \mathrm{mM}$ sodium acetate solution. The absorbance of potassium periodide was read at $353 \mathrm{~nm}$, which indicates the amount of peroxidase. Twenty microliters of hydrogen peroxide $(15 \mathrm{mM})$ was added and the change in the absorbance in $5 \mathrm{~min}$ was recorded. Units of peroxidase activity were expressed as the amount of enzyme required to change the OD by 1 unit per minute. The specific activity was expressed in terms of units per milligram of proteins.

\section{Estimation of glutathione}

The procedure to estimate the reduced glutathione (GSH) level followed to the method as described by Ellman ${ }^{18}$. The homogenate (in $0.1 \mathrm{M}$ phosphate buffer, $\mathrm{pH}$ 7.4) was added with equal volume of $20 \%$ trichloroacetic acid (TCA) containing $1 \mathrm{mM}$ EDTA to precipitate the tissue proteins. The mixture was allowed to stand for $5 \mathrm{~min}$ prior to centrifugation for $10 \mathrm{~min}$ at 200 $\mathrm{rpm}$. The supernatant liquid $(200 \mu \mathrm{l})$ was then transferred to a new set of test tubes and added 1.8 $\mathrm{ml}$ of the Ellman's reagent (5,5'-dithio bis2-nitrobenzoic acid) $(0.1 \mathrm{mM})$ was prepared in $0.3 \mathrm{M}$ phosphate buffer with $1 \%$ of sodium citrate solution). Then all the test tubes make up to the 
volume of $2 \mathrm{ml}$. After completion of the total reaction, solutions were measured at $412 \mathrm{~nm}$ against blank. Absorbance values were compared with a standard curve generated from standard curve from known GSH. The glutathione level in liver was calculated as micromole/g liver.

\section{RESULTS}

\section{Acute toxicity studies}

Acute toxicity studies were carried by up-down regulation method. It was found that the extract at a limit dose from 1500 to $3000 \mathrm{mg} / \mathrm{kg}$ is safe and does not show any mortality.

\section{Isolation of fractions}

Thin-layer chromatography method was carried out using silica gel aluminum plate60F-254, 0.5 mm (TLC plates, Merck). 11 fractions were collected. Above yielded product were pooled into four fractions based on TLC. The yield and appearance of four fractions was given in the Table 1.

Table 1. Appearance and yield of the 4 fractions of Indigofera barber

\begin{tabular}{|c|c|c|}
\hline Fraction & Appearance & Yield \\
\hline Fraction A & Yellow & $150 \mathrm{mg} / \mathrm{g}$ \\
\hline Fraction B & Dark brown greenish & $200 \mathrm{mg} / \mathrm{g}$ \\
\hline Fraction C & Light green & $150 \mathrm{mg} / \mathrm{g}$ \\
\hline Fraction D & Saffron & $300 \mathrm{mg} / \mathrm{g}$ \\
\hline
\end{tabular}

\section{Preliminary phytochemical screening}

Phytochemical screening revealed the presence of alkaloids and carbohydrates in fraction A, saponins in fraction B, glycosides in fraction C and flavonoids in fraction D (Table 2).

Table 2. Preliminary phytochemical screening of fractions of chloroform extract of

\section{Indigofera barberi}

\begin{tabular}{|c|l|c|c|c|c|}
\hline S. No. & Phytochemicals & Fraction A & Fraction B & Fraction C & Fraction D \\
\cline { 2 - 7 } & Alkaloids & + & --- & --- & --- \\
\hline 2 & Tanins & --- & --- & --- & --- \\
\hline 3 & Saponins & --- & + & --- & --- \\
\hline 4 & Glycosides & --- & --- & + & --- \\
\hline 5 & Terpinoids & --- & --- & --- & --- \\
\hline
\end{tabular}




\begin{tabular}{|c|l|c|c|c|c|}
\hline 6 & Carbohydrates & + & --- & --- & --- \\
\hline 7 & Flavonoids & --- & --- & --- & + \\
\hline 8 & Proteins & --- & --- & --- & --- \\
\hline 9 & Aminoacids & --- & --- & --- & --- \\
\hline 10 & Fixed oils & --- & --- & --- & --- \\
\hline 11 & Steroids \& Sterols & --- & --- & --- & -- \\
\hline
\end{tabular}

In-vivo antioxidant activity

Phytochemical screening of the plant showed the presence of flavonoids in fraction D. The present study was taken to assess the in-vivo antioxidant effect of different fractions of chloroform extract of Indigofera barberi whole plant on paracetamol induced toxicity in rats. The result showed that the levels of SOD, catalase, peroxidase and glutathione levels in control group was $65.2 \pm 0.11,14.31 \pm 0.97,0.967 \pm 0.13$ and $98.2 \pm 1.14$ and with paracetamol treated group are $33.6 \pm 0.09,5.5 \pm 0.23,0.131 \pm 0.15$ and $46.1 \pm 5.81$. The levels of SOD, catalase, peroxidase and glutathione with paracetamol treated group declined significantly than that of normal group. With co-administration of fraction D of Indigofera barberi at a dose of $100 \mathrm{mg} / \mathrm{kg}$, the levels of SOD, catalase, peroxidase and glutathione are $61.8 \pm 0.07,10.6 \pm 0.16,0.913 \pm 0.23$ and $87.6 \pm 1.4$. This markedly prevented the paracetamol induced alteration and maintained enzymes level near to normal values (Table 3). Standard treated group also significantly increased the levels of SOD, catalase, peroxidase and glutathione (63.9 $\pm 4.8,12.1 \pm 0.81,0.938 \pm 0.32$ and $91.6 \pm 1.6)$.

Table 3. Radical scavenging activity of fractions of chloroform extract of Indigofera barberi

\begin{tabular}{|c|l|c|c|c|c|c|}
\hline Group & \multicolumn{1}{|c|}{ Treatment } & Dose & $\begin{array}{c}\text { SOD } \\
(\mathrm{U} / \mathrm{mg} \text { protein })\end{array}$ & $\begin{array}{c}\text { Catalase } \\
(\mathrm{U} / \mathrm{mg} \text { protein })\end{array}$ & $\begin{array}{c}\text { Peroxidase } \\
(\mathrm{U} / \mathrm{ml})\end{array}$ & $\begin{array}{c}\text { Glutathione } \\
(\mu \mathrm{M})\end{array}$ \\
\hline I & Control & $2 \mathrm{mi} / \mathrm{kg}$ & $65.2 \pm 0.11$ & $14.31 \pm 0.97$ & $0.967 \pm 0.13$ & $98.2 \pm 1.14$ \\
\hline II & $\begin{array}{l}\text { Paracetamol } \\
\text { treated }\end{array}$ & $2 \mathrm{~g} / \mathrm{kg}$ & $33.6 \pm 0.09$ & $5.5 \pm 0.23$ & $0.131 \pm 0.15$ & $46.1 \pm 5.81$ \\
\hline III & Sylimarin & $100 \mathrm{mg} / \mathrm{kg}$ & $63.9 \pm 4.8$ & $12.1 \pm 0.81$ & $0.938 \pm 0.32$ & $91.6 \pm 1.6$ \\
\hline IV & Fraction A & $50 \mathrm{mg} / \mathrm{kg}$ & $42.4 \pm 0.31$ & $5.67 \pm 0.15$ & $0.551 \pm 0.24$ & $77.1 \pm 0.9$ \\
\hline V & Fraction A & $100 \mathrm{mg} / \mathrm{kg}$ & $51.6 \pm 0.13$ & $6.51 \pm 0.19$ & $0.71 \pm 0.41$ & $82.1 \pm 0.11$ \\
\hline
\end{tabular}




\begin{tabular}{|c|l|c|c|c|c|c|} 
VI & Fraction B & $50 \mathrm{mg} / \mathrm{kg}$ & $41.2 \pm 0.07$ & $6.5 \pm 0.27$ & $0.416 \pm 0.27$ & $73.6 \pm 0.61$ \\
\hline VII & Fraction B & $100 \mathrm{mg} / \mathrm{kg}$ & $44.8 \pm 0.09$ & $6.8 \pm 0.29$ & $0.519 \pm 0.23$ & $79.1 \pm 0.74$ \\
\hline VIII & Fraction C & $50 \mathrm{mg} / \mathrm{kg}$ & $33.6 \pm 0.08$ & $6.32 \pm 0.27$ & $0.321 \pm 0.17$ & $58.4 \pm 1.7$ \\
\hline IX & Fraction C & $100 \mathrm{mg} / \mathrm{kg}$ & $38.1 \pm 0.06$ & $6.50 \pm 0.2$ & $0.481 \pm 0.19$ & $61.3 \pm 1.8$ \\
\hline X & Fraction D & $50 \mathrm{mg} / \mathrm{kg}$ & $55.9 \pm 0.11$ & $9.6 \pm 0.13$ & $0.851 \pm 0.14$ & $83.5 \pm 0.6$ \\
\hline XI & Fraction D & $100 \mathrm{mg} / \mathrm{kg}$ & $61.8 \pm 0.07$ & $10.6 \pm 0.16$ & $0.913 \pm 0.23$ & $87.6 \pm 1.4$ \\
\hline
\end{tabular}

The results are expressed as mean \pm SEM for each group. The data was calculated by one-way

ANOVA. $\mathrm{P}<0.01, \mathrm{P}<0.05$ was considered statistically significant.

Statistical analysis

All analysis were run in triplicates. Data were analysed by an analysis of variance (ANOVA).

Statistical analysis was performed by the Student's t-test and by ANOVA.

\section{DISCUSSION}

In paracetamol induced toxicity, fraction D of chloroform extract of Indigofera barberi treatment increased the depleted levels of cellular GSH significantly in paracetamol induced toxicity in rats. The fraction D of chloroform extract of Indigofera barberi also restored the levels of antioxidant enzymes such as SOD and catalase almost back to the normal levels. SOD plays an vital role in the depletion and elimination of reactive oxygen species (ROS) and protects cells against the deleterious effects of super oxide anion derived from the peroxidative process in liver and kidney tissues ${ }^{19}$ and the observed increase in SOD activity suggests that the fraction Dchloroform extract of Indigofera barberi has an efficient protective mechanism in response to ROS. Catalase, considered as most important $\mathrm{H}_{2} \mathrm{O}_{2}$ removing enzyme and also a key component of antioxidative defense system $^{20}$. Here catalase activity was increased and then restored to normal levels on administration of fraction D of chloroform extract of Indigofera barberi. Peroxidase is an enzyme that catalyzes the reduction of hydroperoxides, including hydrogen peroxides $\left(\mathrm{H}_{2} \mathrm{O}_{2}\right)$, and functions to protect the cell from peroxidative damage ${ }^{21}$. We propose that the additive and synergistic antioxidant activity of phytochemicals such as flavonoids, present in Indigofera barberi are responsible for its potent antioxidant activity.

\section{CONCLUSION}


Phytochemical screening of the fractions showed the presence of flavonoids in fraction D. In our investigation on Indigofera barberi, the enzymatic oxidants such as glutathione, SOD, catalase, and peroxidase were improved in drug treated group as compared to control. Based on this we conclude that fraction D of chloroform extract of Indigofera barberipossessin-vivo antioxidant activity and may be employed in protecting tissues from oxidative stress.

\section{ACKNOWLEDGEMENTS}

Authors are sincerely thankful to Dr. K. Madhava Chetty, Plant Taxonomist, Department of Botany, Sri Venkateswara University, Tirupati, India for authentification of plant materials. Authors are thankful to V. V. Institute of Pharmaceutical Sciences, Gudlavalleru, India for providingnecessary facilities of research work.

\section{REFERENCES}

1. Pourmorad F, Hosseinimehr SJ, Shahabimajd NS. Antioxidant activity, phenol and flavonoid contents of some selected Iranian medicinal Plant. South African Journal of Biotechnolology. 2006;5(1):1142-1145.

2. Ripa FA, Haque M, Haque MIU. In Vitro Antimicrobial, Cytotoxic and Antioxidant Activity of Flower Extract of SaccharumSpontaneum-Linn.European Journal of Scientific Research. 2009;30(3): 478-483.

3. Stuffness M, Douros J. Current status of the NCI plant and animal product program Journal of Natural Products. 1982;45(1):1-14.

4. Baker JT, Borris RP, Carte B. Natural product drug discovery and development: new perspectives on international collaboration. Journal of Natural Products. 1995;58(1):1325-1357.

5. Pham-Huy LA, He H, Pham-Huy C. Free radicals, antioxidants in disease and health. International Journal of Biomedical Science. 2008;4(2):89-96.

6. Willcox JK, Ash SL and Catignani GL. Antioxidants and prevention of chronic disease Food Science and Nutrition. 2004;44(1): 275-295.

7. Van Der Weyden MB, Armstrong RM and Gregory AT. The 2005 Noble prize in Physiology or Medicine. Medical Journal of Australia. 2005;183(11):612-614. 
8. Nagarajan NS, Murugesh N, Thirupathy KP, Radha N, Murali A. Antidiabetic and antihyperlipidemic effects of Cleome feline. Fitoterapia. 2005;76(1):310-315.

9. Nalamolu KR, Srinivasu N. Antidiabetic and renoprotecticve effects of chloroform extract of Terminalia chebula seeds in streptozotocin induced diabetic rats. BMC Complementary and Alternative Medicine. 2006;58(1):128-135.

10. Phuong ML, Ali BA, Aziz E, Abdellatif S, Yahia C, Pierre SH. The petroleum ether extract of Nigella sativa exerts lipid lowering and insulinsensitizing action in the rats. Journal of Ethnopharmacology. 2004;94(1):251-259.

11. Madhava Chetty K, Sivaji K, Tulasi Rao K. India $4^{\text {th }}$ edition, Student offset Printers, Tirupathi. 2013.

12. Sree Latha Devi, PhD Thesis, Rayalaseema University, Andhra Pradesh. 2011.

13. Khandelwal KR. Practical Pharmacognosy Techniques and Experiments. 2000;149-156.

14. OECD Guidelines for testing of chemical, revised draft guidelines, Acute Oral ToxicityUp-and-Down Procedure. 2001;30:425.

15. Beauchamp C, Fridovich I. Superoxide dismutase: improved assays and an assay applicable to acrylamide gels. Analytical Biochemistry Review. 1971;44(1):276-287.

16. Aebi H. Catalase in vitro. Methods in Enzymology. 1984;105(1):121-126.

17. Nicholos MA. In vitro double transposition for DNA identification. Analytical Biochemistry. 1986;4(1):311-345.

18. Ellman GL. A new and rapid colorimetric determination of acetylcholinesterase activity. Achieves of Biochemistry and Biophysics. 1995;82(2):70 $\square 77$.

19. Fridovich I. Superoxide radical and superoxide dismutases. Annual Review of Biochemistry. 1975;44(1):147-159.

20. Luck H. Academic Press, New York. 1971;3(1):885-894.

21. Sandhir R, Gill KD. Effect of lead on lipid peroxidation in liver of rats. Indian Journal of Experimental Biology. 1999;37(1):762-766. 